\title{
Quality kinetics and storage stability studies of ready to eat peanut chutney
}

\begin{abstract}
Ready to eat peanut (Arachis hypogaea) chutney was developed and the recipe was optimized by sensory evaluation. The effect of vinegar percentage, packaging material and storage temperature over the RTE chutney was studied. Taguchi orthogonal array method was adopted for designing experiment. Quality parameters viz. moisture content, $\mathrm{pH}$, carbohydrates, protein, fat content and overall acceptability were estimated for 40days at an interval of 10days. Quality kinetics was studied and kinetic rate constant, activation energy $\left(\mathrm{E}_{\mathrm{a}}\right)$ and temperature coefficient $\left(\mathrm{Q}_{10}\right)$ were estimated. Storage studies were analyzed based on $\mathrm{t}_{09}$ (Shelf life period) and $\mathrm{t}_{05}$ (Half life period). Based on the experiments, Treatment $\mathrm{T}_{3}(10 \%$ of vinegar, packed in glass bottle and stored at refrigeration temperature) was found to be an optimal solution.
\end{abstract}

Keywords: Peanut chutney; Storage Kinetics; Activation energy; Half life period
Volume I Issue 3 - 2014

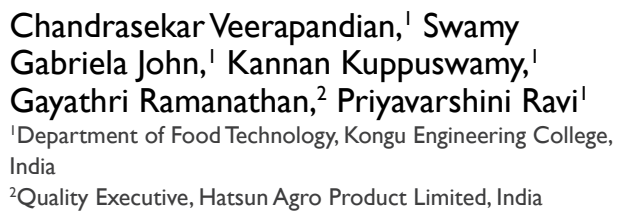

Correspondence: Chandrasekar Veerapandian, Department of Food Technology, Kongu Engineering College, Tamilnadu, India, Tel +919944587326, Email chandrufpe@gmail.com

Received: April 15, 2014 | Published: June 24, 2014

\section{Introduction}

Peanut (Arachis hypogaea), is a member of the legume family (Fabaceae). They are a rich source of energy and contain nutrients, minerals, antioxidants and vitamins that are essential for optimum health. The nuts are a good source of resveratrol, vitamin E, B-complex groups of vitamins and minerals. Peanuts are eaten as raw nuts, used for oil extraction or used in recipes for chutney. Peanut based snacks include salted peanuts, peanut butter, peanut brittle, and shelled nuts (plain/roasted). Chutney is an important dish in Indian cuisine and they are made from fruits or vegetables, or a mixture of the two, which are chopped, cooked, mixed with spices, vinegar and other ingredients and reduced to a smooth pulp. Chutneys are preserved in several ways such as using oil, vinegar or citrus juice fermentation in the presence of salt. Vinegar is a main ingredient in all chutneys. The acetic acid in vinegar acts as a natural preservative. Several instant chutney powders based on curry leaf chutney powder, ${ }^{1}$ tamarind leaf chutney powder, ${ }^{2}$ raw tamarind chutney powder, ${ }^{3}$ raw mango chutney powder ${ }^{4}$ and instant chutneys from pudina and gongura ${ }^{5}$ were studied earlier.

Sensory evaluation was done for ready to eat amla chutney after twomonths of storage period. ${ }^{6}$ Murray et al., ${ }^{7}$ used the sensory evaluation to optimize the ingredients based on colour, taste, flavor, consistency and overall acceptability. The proximate composition of instant tamarind chutney powder such as moisture, $\mathrm{pH}$, acidity, carbohydrate, and fat was estimated. ${ }^{3}$ The moisture content, $\mathrm{pH}$, acidity, carbohydrate, fat and total phenolic of ready eat Amala chutney were estimated at 10days interval. ${ }^{6}$ Narsing Rao et al., ${ }^{8}$ reported that the moisture content was increased in instant tomato pickle mix regardless of the packaging material during storage period. Prabhakara et al., ${ }^{9}$ observed that the acidity of the instant pulihora mix changed from 4.22 to 4.77 after sixmonths of storage period. The $\mathrm{pH}$ of the pickle stored for 180days in sterilized air tight bottle was found decreased. ${ }^{10}$ Quality kinetics is defined as rate of change quality parameters. It used to predict the time span for which a newly developed product will maintain its wholesomeness at a specified temperature. Kinetics provides the mechanism of changes involved in active ingredients and predicts the degree of change that will occur after a given period of time. The kinetics of the oxidation process corresponded to an autocatalytic reaction was studied by Frankel. ${ }^{11}$ Gomez-Alonso et al., ${ }^{12}$ kinetic behavior of the peroxide value was measured for purified olive oil. The change in hydroxy methyl furfural content of instant pearl millet based Kheer mix samples was followed the first order reaction. ${ }^{13}$ Oliveira et al. ${ }^{14}$ developed shelf-life kinetic model for modified atmosphere packaging of fresh sliced mushrooms. The color change and 5-hydroxymethyl furfural formation in zile pekmezi during storage was studied by Tosun ${ }^{15}$ and also evaluated the reaction orders, rate constants and activation energy. Kinetic model was established to explain temperature dependence of ascorbic acid loss. ${ }^{16}$

The reaction rate constant quantifies speed of a reaction. Sergio Gomez-Alonso et al., ${ }^{12}$ observed that the reaction rate constant for change in peroxide value of purified olive oil was increased from 1.10 x $10-8$ to $7.52 \times 10-81 / \mathrm{s}$ by increase in temperature from 25 to $75^{\circ} \mathrm{C}$. Labuza $^{17}$ has reported that quality loss equation and stated that the change in the concentration of measurable quality parameter with time is equal to the product of the rate constant (k) and the concentration of measurable quality parameter. Polydera et al., ${ }^{16}$ observed that the reaction rate constant of ascorbic acid degradation was lower for high pressurized juice than thermally treated juice and extend its shelf life. Activation energy was 61.1 and $43.8 \mathrm{KJ} / \mathrm{mol}$ for high pressurized and thermally treated bottled juice respectively. ${ }^{18}$ The relationship between reaction rate constant and activation energy is expressed by Arrhenius equation. Arrhenius equation describes the effect of storage temperature on degradation of quality parameters.

Rate of most reactions is increasing with a rise in temperature up to 2 to 3 times with each $10^{\circ} \mathrm{C}$ rise in temperature. The $\mathrm{Q}_{10}$ temperature coefficient is a measure of the rate of change of a biological or chemical system as a consequence of increasing the temperature by $10^{\circ} \mathrm{C} .{ }^{19} \mathrm{Q}_{10}$ is a unit less quantity and it is the factor of rate changes. If the reaction rate increases with an increase in temperature then the $\mathrm{Q}_{10}$ will be greater than $1 . \mathrm{Q}_{10}$ is a useful to express the temperature dependence of a process. Storage stability describes the extent to which the properties of a food substance or product remain with 
intact at a certain temperature. Properties may be physical, chemical, microbiological, toxicological or performance properties such as disintegration and dissolution. Storage stability is explained by both shelf life and half life. The shelf life of the peanut chutney depends on retention of quality parameters. Shelf life is the recommendation of time that products can be stored, during which the defined quality of a specified proportion of the goods remains acceptable under expected (or specified) conditions of distribution, storage and display. ${ }^{20}$ Shelf life is the time required to reduce $10 \%$ of concentration of quality parameters from its initial value i.e. $90 \%$ retention of original quality. Half-life $\left(t_{0.5}\right)$ is the time required for a quantity to fall to half its value as measured at the beginning of the time period. Hence the aim of the present study was

i. To prepare a peanut chutney and optimize the recipe.

ii. To study the quality kinetics and estimate the reaction rate constant, activation energy and temperature coefficient for different storage periods.

iii. To study the storage stability based on shelf life and half life period of peanut chutney and to optimize the treatment for better storage stability.

\section{Methods and materials}

\section{Recipe optimization and storage}

The good quality peanuts were roasted along with sand at 100$110^{\circ} \mathrm{C}$. Other ingredients such as curry leaves, cumin asafetida and garlic were fried with oil. Ground the roasted peanuts, fried ingredients, chilli powder, tamarind and salt along with water. Sensory evaluation was done by 9 point hedonic scale and 15 semi skilled panel members were used. Name of the factors and their levels affecting the storage of ready to eat peanut chutney is shown in Table 1. Taguchi orthogonal array L4 (23) method was used for designing experiment for storage. The prepared ready to eat chutney was packed and stored.

Table I Factors and levels

\begin{tabular}{llll}
\hline \multirow{2}{*}{$\begin{array}{l}\text { S. } \\
\text { no }\end{array}$} & $\begin{array}{l}\text { Name of the factors } \\
\text { and symbols }\end{array}$ & \multicolumn{2}{l}{ Level } \\
\cline { 3 - 4 } & $\mathbf{I}$ & $\mathbf{2}$ \\
\hline 1 & Vinegar (A) & $5 \%$ & $10 \%$ \\
2 & Packaging material (B) & Glass bottle & Aluminum foil \\
3 & $\begin{array}{l}\text { Storage temperature } \\
\text { (C) }\end{array}$ & $\begin{array}{l}\text { Room } \\
\text { temperature } \\
\left(35 \pm 2^{\circ} \mathrm{C}\right)\end{array}$ & $\begin{array}{l}\text { Refrigeration } \\
\text { temperature } \\
\left(5 \pm 2^{\circ} \mathrm{C}\right)\end{array}$ \\
\hline
\end{tabular}

\section{Estimation of quality parameters}

Triplicate samples were used for estimating all quality parameters. The moisture content and of peanut chutney was determined and recorded as per AOAC method. $\mathrm{pH}$ of the sample was measured using a digital $\mathrm{pH}$ meter (Elico make).

The carbohydrate content was calculated by Anthrone method. ${ }^{21}$ $0.1 \mathrm{~g}$ of the sample was taken in boiling tube and $3 \mathrm{ml}$ of $2.5 \mathrm{NHCl}$ was added. Boiled the solution for 3 hours and cooled to room temperature. Sodium carbonate as pellet was added to the solution till effervescence ceases and made up to $100 \mathrm{ml}$ by distilled water.
Solution was centrifuged for $5 \mathrm{~min}$ at $5000 \mathrm{rpm}$. Supernatant $(0.5$ and $1.0 \mathrm{ml})$ and glucose working standard solution $(0.2,0.4,0.6,0.8$, and $1 \mathrm{ml})$ were taken in test tubes for analysis. Blank was also maintained. Distilled water was added to all the test tubes to make up $1.0 \mathrm{ml}$ and $4.0 \mathrm{ml}$ of anthrone reagent was added to the test tubes. Test tubes were heated for 8 minutes and cooled. Cooled samples were analysed by UV spectrophotometer at $630 \mathrm{~nm}$. A standard graph was prepared. From the graph, values for unknown samples were estimated and expressed in $\mathrm{g} / 100 \mathrm{~g}$ of sample.

The protein content was estimated by Folin-Ciocalteau method..$^{21}$ $0.5 \mathrm{~g}$ of the sample was taken and ground well in a pestle and mortar with $5-10 \mathrm{ml}$ of buffer solution. The solution was centrifuged and the supernatant was collected. $0.2-1 \mathrm{ml}$ of the working standard was taken into a series of test tubes and also 0.1 and $0.2 \mathrm{ml}$ of the supernatant was taken into another two test tubes. Make up the volume to $1 \mathrm{ml}$ in all the test tubes with distilled water. A tube with $1 \mathrm{ml}$ of water serves as the blank. $5 \mathrm{ml}$ of alkaline copper solution (Mixture of $50 \mathrm{ml}$ of $2 \%$ sodium carbonate in $0.1 \mathrm{~N}$ sodium hydroxide and $0.5 \%$ copper sulphate in $1 \%$ of potassium sodium tartarate) was added to each test tube including blank. All the tubes were mixed well and allowed to stand for $10 \mathrm{~min}$. Then $0.5 \mathrm{ml}$ of Folin-Ciocalteau reagent to all the tubes and mixed well. The tubes were incubated at room temperature in the dark for $30 \mathrm{~min}$. The blue color was developed. Developed blue colour was measured using UV Spectrophotometer at $660 \mathrm{~nm}$. A standard graph was drawn. From the graph, protein content was estimated and expressed in $\mathrm{g} / 100 \mathrm{~g}$ of sample.

Crude fat content was determined by solvent extraction method and expressed in $\mathrm{g} / 100 \mathrm{~g}$ of sample.

\section{Quality kinetics}

Graphs were plotted between quality parameters and time. First order kinetic equation was fitted for all the graphs in order to describe the behavior of degradation of quality parameters during storage and coefficient of determination was determined. The reaction rate constant (k) was obtained from the following first order kinetic equation (1).

$$
\mathrm{h}[C]=\mathrm{h}\left[C_{0}\right]-k
$$

Where, $\mathrm{C}_{\mathrm{O}}$ is initial concentration of quality parameter, $\mathrm{C}$ is concentration of quality parameter at time $\mathrm{t}, \mathrm{k}$ is reaction rate constant, 1 /days and $t$ is storage time.

Similarly, activation energy $\left(\mathrm{E}_{\mathrm{a}}\right)$ and temperature coefficient $\left(\mathrm{Q}_{10}\right)$ were calculated from the equations (2) and (3) respectively.

$$
\begin{aligned}
& \text { h } \frac{k_{2}}{k_{1}}=E_{a} / R\left(T_{2}-T_{1}\right) \\
& \boldsymbol{Q}_{\mathbf{0}}=\left(\boldsymbol{k}_{2} / \boldsymbol{k}_{\mathbf{1}}\right)^{\mathrm{o} /\left(T_{2}-T_{1}\right)}
\end{aligned}
$$

Where, $\mathrm{k}_{1}$ and $\mathrm{k}_{2}$ are the reaction rate constant at temperature $\mathrm{T}_{1}$ and $\mathrm{T}_{2} \mathrm{R}$ is universal gas constant, $8.144 \mathrm{~J} / \mathrm{mol} . \mathrm{K}$ and $\mathrm{E}_{\mathrm{a}}$ is activation energy $\mathrm{J}$.

\section{Storage stability}

Time taken to decrease of quality parameters to undesired a 
level i.e. Retention of quality parameters up to the desired level of the consumers is termed as shelf life of the product. Half life period explains the degradation of $50 \%$ of quality parameters from its original value. Both shelf life $\left(\mathrm{t}_{0.9}\right)$ and half life $\left(\mathrm{t}_{0.5}\right)$ were calculated using

the following formula given by equations (4) and (5).

$$
\begin{aligned}
& \mathrm{t}_{0.9}=0.105 / \mathrm{k} \\
& \mathrm{t}_{0.5}=0.693 / \mathrm{k}
\end{aligned}
$$

Where, $\mathrm{t}_{0.9}$ is shelf life, days and $\mathrm{t}_{0.5}$ is half life,days and $\mathrm{k}$ is reaction rate constant, 1 /days.

\section{Overall acceptability}

Overall acceptability of peanut chutney was estimated by sensory evaluation for 40days at 10days of interval.

\section{Results and discussion}

\section{Recipe optimization}

Ready to eat peanut chutney was prepared by the procedure given in the methods and materials. The ingredients were optimized by sensory evaluation based on highest score of color, taste, flavor, consistency and overall acceptability. The optimized recipe is given in the Table 2. Experimental design is shown in the Table 3 and the packed ready to eat peanut chutney was stored at different treatment condition and quality parameters were analyzed for 40days at every 10days interval.

Table 2 Optimized recipe for ready to eat peanut chutney

\begin{tabular}{ll}
\hline Ingredients & Quantity, g \\
\hline Peanut & 70 \\
Curry leaves & 4 \\
Tamarind & 5 \\
Garlic & 4 \\
Turmeric powder & 0.2 \\
Cumin & 0.4 \\
Salt & 6 \\
Chilly powder & 0.7 \\
Oil & 6 \\
Asafetida & 0.2 \\
Water & 10 \\
\hline
\end{tabular}

\section{Quality parameters}

The change of moisture content during storage is depicted in the Figure 1. From the Figure 1, it is observed that the moisture content was increased from $15.6 \% \mathrm{wb}$ to $17.22 \% \mathrm{wb}$ as increase in storage period. Increase of moisture content might be due to the hydrolysis of carbohydrate, protein and fat. Also, this could have happened due to permeability of packaging material. Increasing in moisture content increases the water activity and thus decreases the quality and storage. The similar kind of results has been reported by Narsing Rao et al., ${ }^{8}$ for tomato powder and instant tomato pickle. This result also accordance with Mishra et al., 6

Change in $\mathrm{pH}$ of was gradually decreased from 5 to $4.8 \%$ as increase in storage period and it is shown in the Figure 2. This might be due to conversion of fat into fatty acids. Variation in the $\mathrm{pH}$ content was very low than other quality parameters. Conversion of fatty acids is due to microorganism, principle active components of spices available in the chutney could have arrested the growth of microorganism. Decreasing of $\mathrm{pH}$ was due to increase in acidity and thus, it will prevent the growth of the microorganisms. However, more acidity causes sour taste to the product. Prabhakara et al., ${ }^{9}$ and Tamilselvi et al., ${ }^{10}$ observed similar kind of results in their studies. Mishra et al. ${ }^{6}$ has also reported the similar trend.

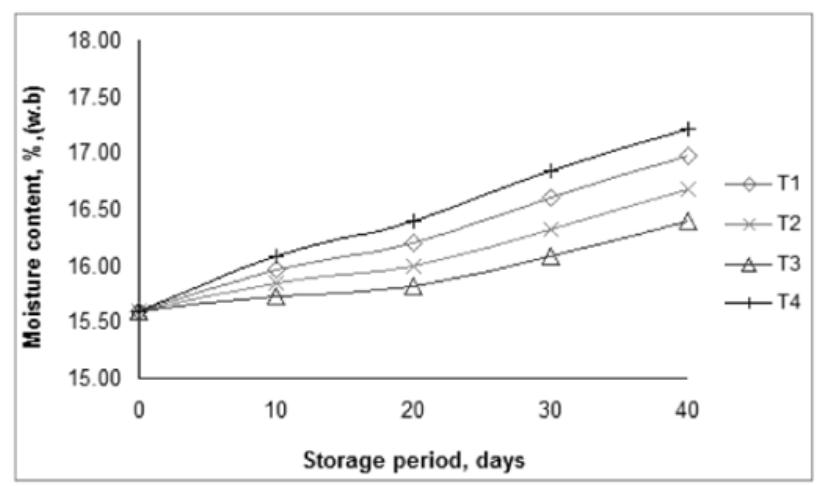

Figure I Effect of moisture content of ready to eat peanut chutney on storage period.

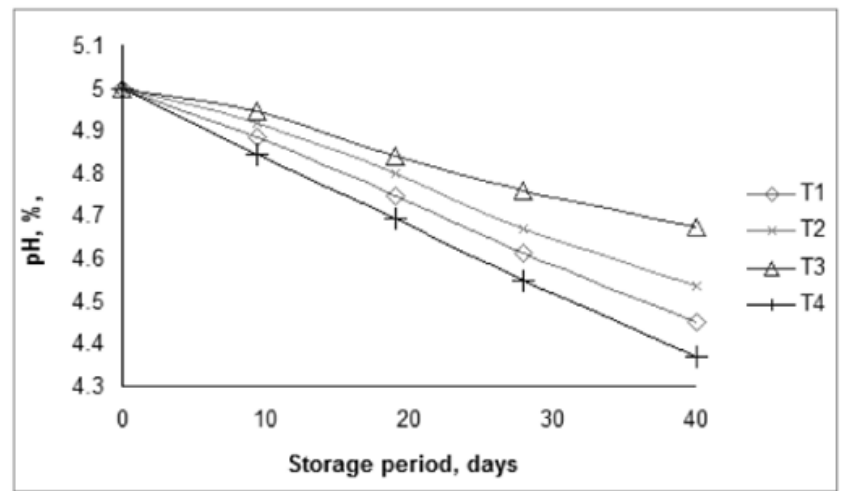

Figure 2 Effect of $\mathrm{pH}$ content of ready to eat peanut chutney on storage period.

Table 3 Taguchi orthogonal array L4 $\left(2^{3}\right)$

\begin{tabular}{ccccc}
\hline \multirow{2}{*}{ S. no } & \multicolumn{2}{l}{ Factors and levels } & Treatment no \\
\cline { 2 - 4 } & A & B & C & \\
\hline I & $\mathrm{I}$ & $\mathrm{I}$ & $\mathrm{I}$ & $\mathrm{T}_{1}$ \\
2 & $\mathrm{I}$ & 2 & 2 & $\mathrm{~T}_{2}$ \\
3 & 2 & $\mathrm{I}$ & 2 & $\mathrm{~T}_{3}$ \\
4 & 2 & 2 & $\mathrm{I}$ & $\mathrm{T}_{4}$ \\
\hline
\end{tabular}

Change in carbohydrate, protein and fat was illustrated in the Figures 3-5. Changes of quality parameters might be due to hydrolyzation due to cleavage of $\alpha-1,4$ hydrogen bonds. Sometimes oxidation process also decreases the carbohydrate, protein and fat quality parameters. Subsequently, hydrolyzation increases the moisture content in the chutney and oxidation process fade affects colour of the chutney and Prabhakara Rao et al., ${ }^{22}$ have reported the similar kind of changes in his studies and Martins et al., ${ }^{23}$ found that the starch content was decreased during storage of frozen green beans. 
Change in fat content affects the texture of the product. Narsing Rao et al., ${ }^{8}$ have been reported the change in fat of tomato powder and instant tomato pickles. It may due to conversion of fat into fatty acids and peroxide formation. It gives the rancid flavor to the product.

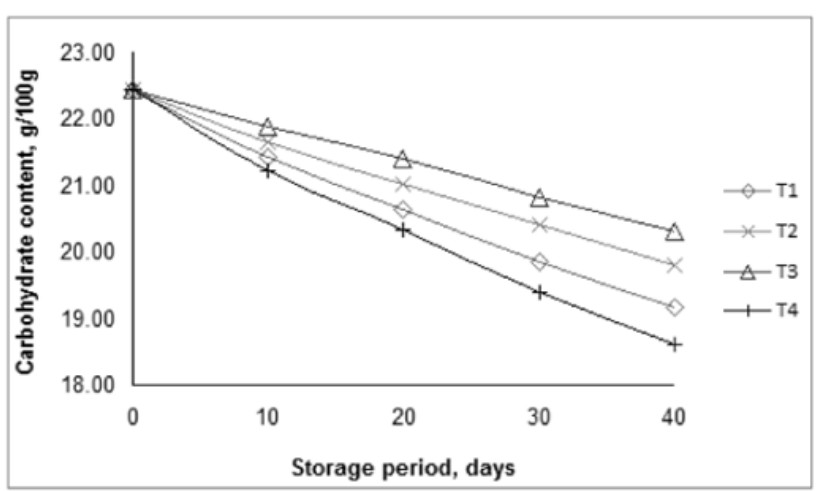

Figure 3 Effect of carbohydrate content of ready to eat peanut chutney on storage period.

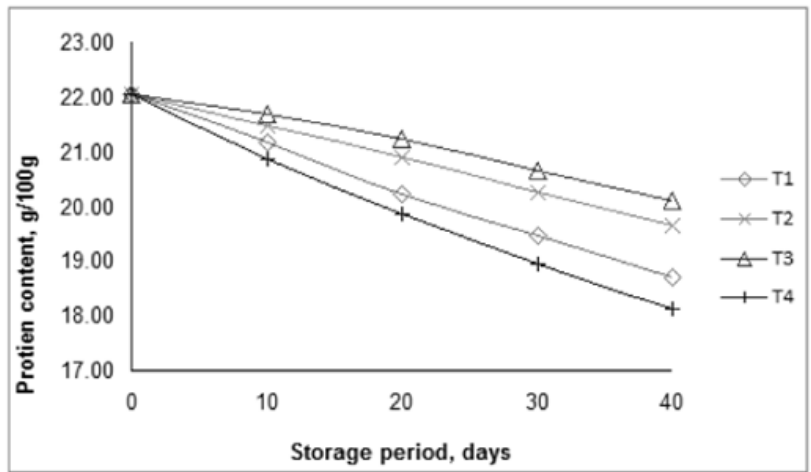

Figure 4 Effect of protein content of ready to eat peanut chutney on storage period.

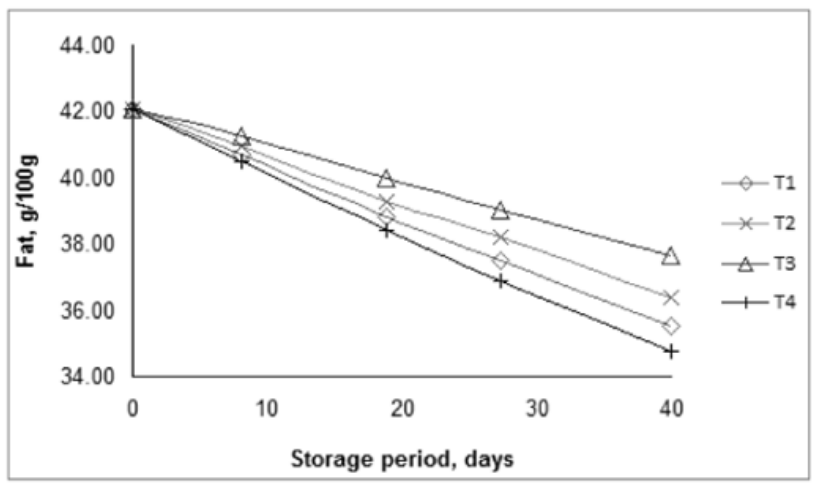

Figure 5 Effect of fat content of ready to eat peanut chutney on storage period.

\section{Quality kinetics}

Figures 6-9 shows the graph between the quality parameters and time and it is observed that the rate of change of quality parameters such as $\mathrm{pH}$, carbohydrate, protein and fat was decreased with the increase in storage period and followed the first order kinetics. The rate of change of quality parameter was depending upon the packaging material, vinegar percentage and storage temperature. Polydera et al., ${ }^{16,18}$ have reported the vitamin $\mathrm{C}$ degradation kinetics for orange juice. The rate constants were obtained from the first order kinetic equation and furnished in the (Table 4). Rate constants are varied from 0.0011 to 0.0049 days -1 with high coefficient of determination. From this table, it is observed that the rate constant of the $\mathrm{pH}$, carbohydrate, protein and fat were ranging from 0.0005 to $0.012,0.0025$ to 0.0046 , 0.0023 to 0.0049 and 0.0028 to 0.0047 days- 1 , respectively. The lower the reaction rate constant, lesser the degradation rate and vice versa. Martins et al., ${ }^{23}$ and Tosun ${ }^{15}$ has reported the rate constants for quality parameters.

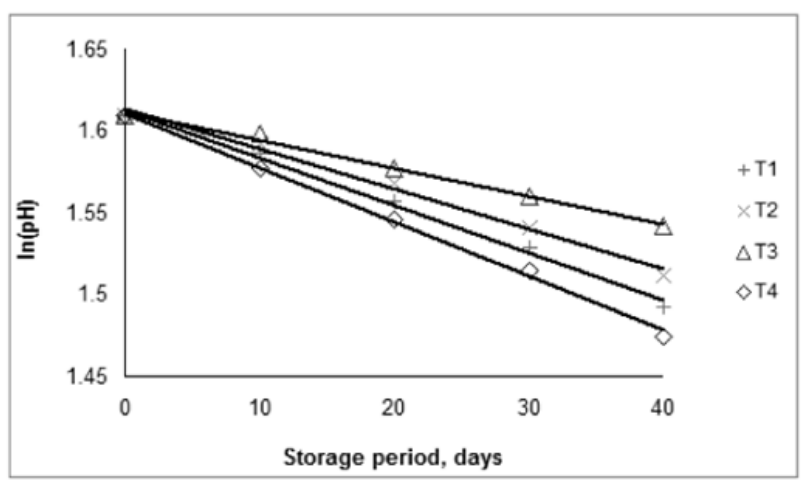

Figure 6 Plot on $\ln (\mathrm{pH})$ Vs storage period.

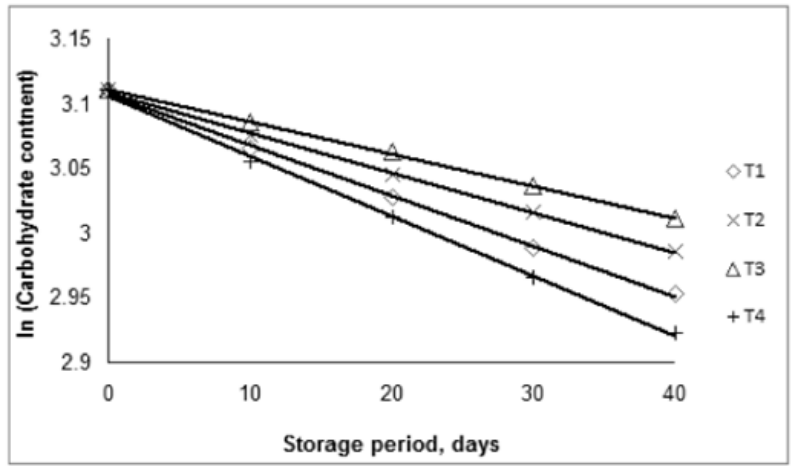

Figure 7 Plot on In (Carbohydrate content) Vs storage period.

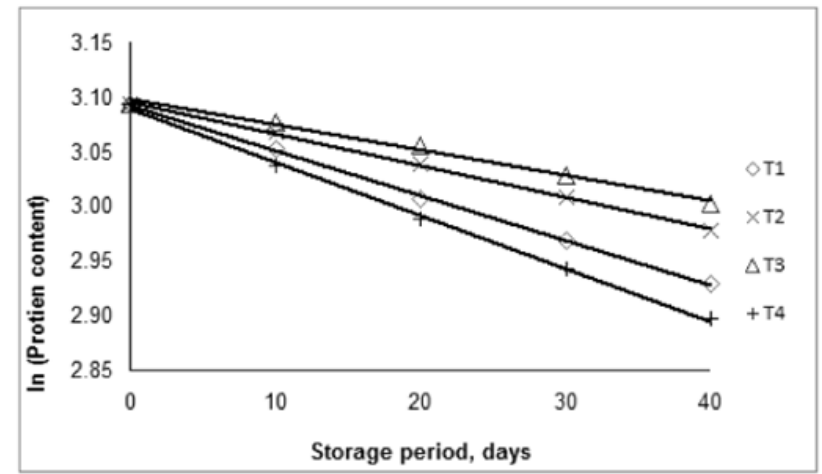

Figure 8 Plot on In (Protein content) Vs storage period.

Graph was plotted between plotted between $\ln (\mathrm{k})$ vs $1 / \mathrm{T}$ and illustrated in the Figures 10-13. Activation energy was obtained from graphical method. The activation energy values for glass bottles were found to be $18.709,10.323,13.420,10.422 \mathrm{KJ} / \mathrm{mol}$ for $\mathrm{pH}$, carbohydrate, protein and fat, respectively and for aluminum foil $6.826,9.162,12.4177$ and $9.41 \mathrm{KJ} / \mathrm{mol}$ for $\mathrm{pH}$, carbohydrate, protein and fat, respectively. Tosun ${ }^{15}$ reported the activation energy for 
quality parameters and Bunkar et al., ${ }^{13}$ has also reported similar kind of results in his work. Similarly, the temperature coefficient value of $\mathrm{pH}$, carbohydrate, protein and fat is $1.3,1.15,1.21$, and 1.14 for glass bottle, respectively and $1.1,1.14,1.19$ and 1.16 for aluminum foil, respectively. All the temperature coefficient values are more than one, therefore the degradation of quality parameters are depending upon the temperature. Both activation energy and temperature coefficient values are presented in the Table 5. From the table it is inferred that, both activation energy and temperature coefficient value is significantly higher for glass bottle than aluminum foil.

Table 4 Rate constants, K, I/S

\begin{tabular}{lllllllll}
\hline \multirow{2}{*}{ Treatments } & $\mathbf{p H}$ & & $\mathbf{C H O}$ & \multicolumn{3}{c}{ Protein } & \multicolumn{3}{l}{ Fat } \\
\cline { 2 - 9 } & $\mathbf{k}$ & $\mathbf{R}^{2}$ & $\mathbf{k}$ & $\mathbf{R}^{2}$ & $\mathbf{k}$ & $\mathbf{R}^{2}$ & $\mathbf{k}$ & $\mathbf{R}^{2}$ \\
\hline T1 & 0.0029 & 0.994 & 0.0039 & 0.997 & $0.004 \mathrm{I}$ & 0.9992 & 0.0042 & 0.9934 \\
T2 & 0.0025 & 0.990 & $0.003 \mathrm{I}$ & 0.998 & 0.0029 & 0.9989 & 0.003 & 0.9878 \\
T3 & 0.0017 & 0.992 & 0.0025 & 0.999 & 0.0023 & 0.9914 & 0.0028 & 0.9908 \\
T4 & 0.0033 & 0.997 & 0.0046 & 0.997 & 0.0049 & 0.998 & 0.0047 & 0.9947 \\
\hline
\end{tabular}

Table 5 Effect of packaging material on $\mathrm{E}_{\mathrm{a}}$ and $\mathrm{Q}_{10}$

\begin{tabular}{lllllllll}
\hline \multirow{2}{*}{ Packaging material } & $\mathbf{p H}$ & \multicolumn{3}{c}{$\mathbf{C H O}$} & \multicolumn{3}{c}{ Protein } & \multicolumn{3}{c}{ Fat } \\
\cline { 2 - 9 } & $\mathbf{E}_{\mathbf{a}}$ & $\mathbf{Q}_{\mathbf{1 0}}$ & $\mathbf{E}_{\mathbf{a}}$ & $\mathbf{Q}_{\mathbf{1 0}}$ & $\mathbf{E}_{\mathbf{a}}$ & $\mathbf{Q}_{\mathbf{1 0}}$ & $\mathbf{E}_{\mathbf{a}}$ & $\mathbf{Q}_{\mathbf{1 0}}$ \\
\hline Glass Bottle & 18.709 & 1.30 & 10.323 & 1.16 & 13.420 & 1.21 & 10.422 & 1.14 \\
Aluminum Foil & 6.826 & 1.10 & 9.162 & 1.14 & 12.177 & 1.19 & 9.413 & 1.16 \\
\hline
\end{tabular}

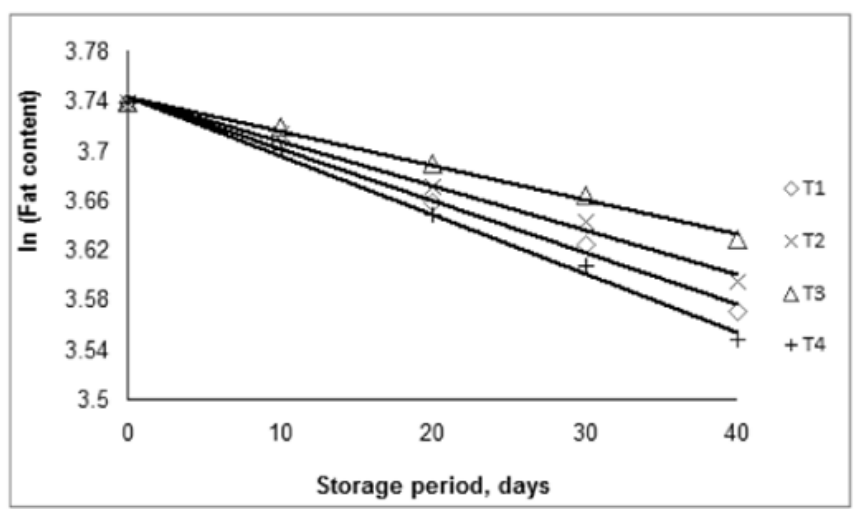

Figure 9 Plot on In (Fat content) Vs storage period.

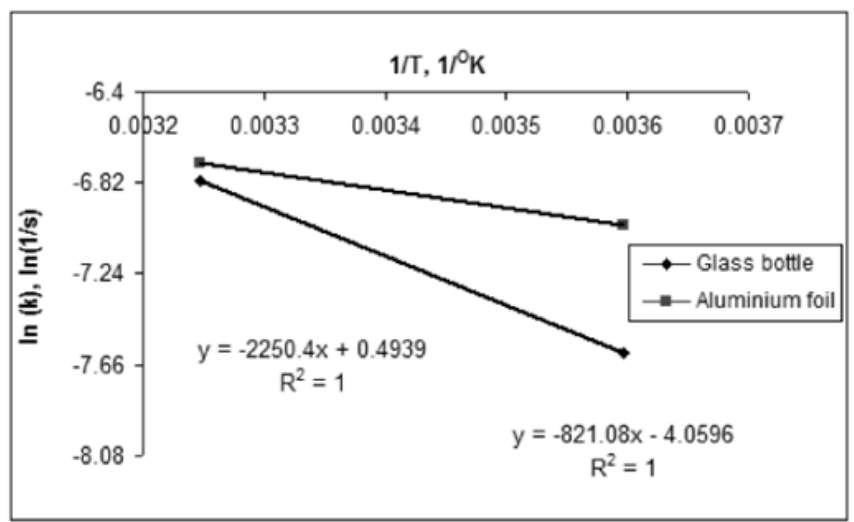

Figure 10 Graph of $\ln (\mathrm{k})$ of $\mathrm{pH}$ vs I/T.

\section{Storage stability}

The shelf life and half life were estimated and given in the Table 6. Shelf life was varied from 22.34 to 210.00 days. Shelf life of $\mathrm{pH}$, carbohydrate, protein and fat are varied from 87.50 to $210.00,22.83$ to 42.00 and 21.42 to 45.65 and 22.34 to 37.50 days, respectively. Likewise, half life of $\mathrm{pH}$, carbohydrate, protein and fat are varied from 141.43 to $1386.00,150.65$ to 277.20 and 141.43 to 301.30 and
147.45-247, respectively. The Polydera et al., ${ }^{16,18}$ have reported the vitamin $\mathrm{C}$ degradation kinetics for orange juice and reported the shelf life studies. It is observed from the Table 6, both the shelf life and half life follows the similar trend. Based on the results of $\mathrm{t}_{0.9}$ and $\mathrm{t}_{0.5}$, treatment $\mathrm{T}_{3}$ was found better than other treatments due to slower degradation of quality parameters. Although aluminum foil was used in $T_{3}$, vinegar and storage temperature also influenced the retention of quality parameters. The results are substantiating by the results of sensory evaluation after $40^{\text {th }}$ day of storage.

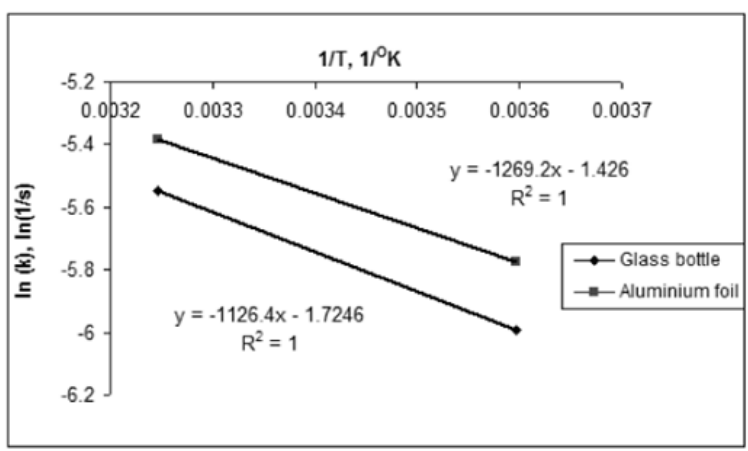

Figure II Graph of In (k) of carbohydrate Vs I/T.

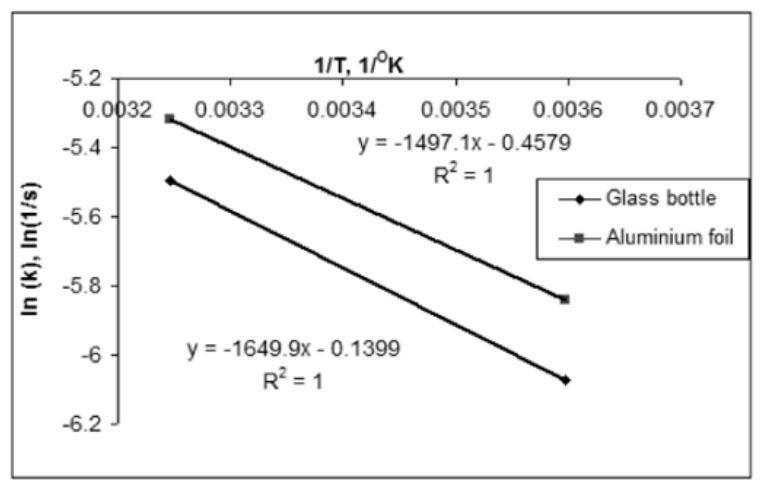

Figure 12 Graph of In (k) of protein Vs I/T. 
Table 6 Shelf-life $(\mathrm{t} 0.9)$ and half life $\left(\mathrm{t}_{0.5}\right)$ of peanut chutney

\begin{tabular}{|c|c|c|c|c|c|c|c|c|c|}
\hline \multirow{2}{*}{\multicolumn{2}{|c|}{ Treatments }} & \multicolumn{2}{|l|}{ PH } & \multicolumn{2}{|l|}{$\mathrm{CHO}$} & \multicolumn{2}{|c|}{ Protein } & \multicolumn{2}{|l|}{ Fat } \\
\hline & & $\mathbf{t}_{0.9}$ & $\mathbf{t}_{0.5}$ & $\mathbf{t}_{0.9}$ & $t_{0.5}$ & $t_{0.9}$ & $t_{0.5}$ & $\mathbf{t}_{0.9}$ & $\mathbf{t}_{0.5}$ \\
\hline \multicolumn{2}{|l|}{ TI } & 95.45 & 630.00 & 26.92 & 177.69 & 25.60 & 169.02 & 25.00 & 165.00 \\
\hline \multicolumn{2}{|l|}{$\mathrm{T} 2$} & 116.67 & 770.00 & 33.87 & 223.55 & 36.20 & 238.97 & 35.00 & 231.00 \\
\hline T3 & 210.00 & 1386.00 & 42.00 & 277.20 & 45.65 & 301.30 & 37.50 & 247.50 & \\
\hline T4 & 87.50 & 577.50 & 22.83 & 150.65 & 21.42 & 141.43 & 22.34 & 147.45 & \\
\hline
\end{tabular}

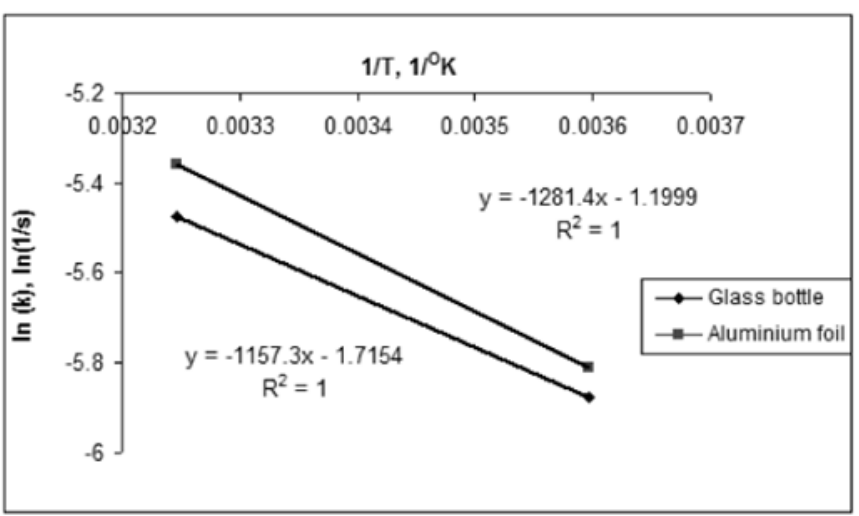

Figure 13 Graph of In (k) of fat Vs I/T.

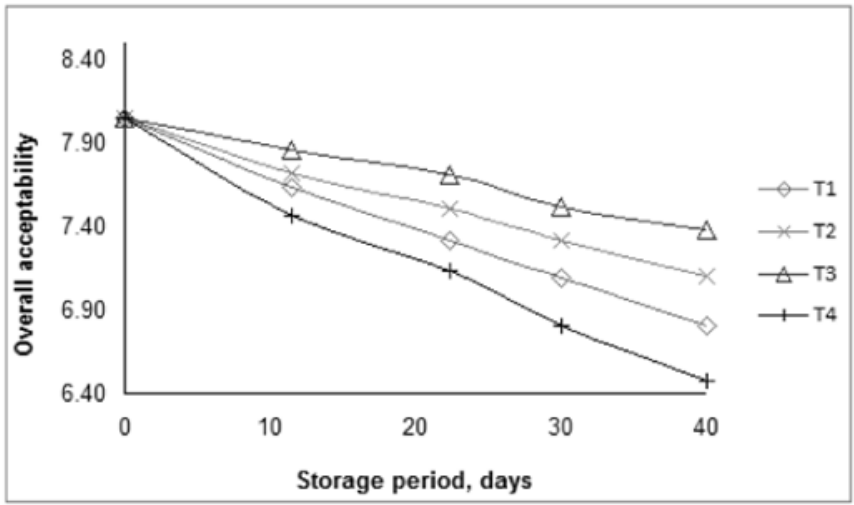

Figure I4 Effect of overall acceptability of peanut chutney on storage studies.

\section{Overall acceptability}

Overall acceptability of the stored product was changed as a function of storage period depicted in the Figure 14. Change in sensory quality associated with the change in quality parameters. From the results it is clearly indicating that the quality parameters are gradually decreasing as increase in storage period. For instance, the decrease in $\mathrm{pH}$ content affects the flavour of the product, similarly degradation of carbohydrate, protein and fat affects the quality color, flavour and consistency of the product. The Polydera et al., ${ }^{16,18}$ have reported the sensory evaluation studies as a function of storage period. Lower overall acceptability found in treatment 4 compared to other treatments. The changes in sensory scores are due to the degradation of quality parameters loss.

\section{Conclusion}

Ready to eat peanut chutney was developed and recipe was optimized. Taguchi orthogonal array method was adopted. Quality kinetics was studied. Reaction rate constant, activation energy and temperature coefficient were estimated. Shelf life and half life of the peanut chutney were calculated. At the end of the $40^{\text {th }}$ day of storage period, the treatment $\mathrm{T}_{3}$ was found better and this was validated by the analyzing overall acceptability. Therefore the study concludes that the ready to eat peanut can be stored upto 40days in the combination of vinegar $10 \%$, glass bottle and refrigerated.

\section{Acknowledgements}

We sincerely express our gratitude to Kongu Engineering College for facilities provided to carry out the work.

\section{Conflict of interest}

Author declares that there is no conflict of interest.

\section{References}

1. Balaswamy K, Jyothirmayi T, Rao DG. Studies on preparation of curry leaf (Murraya koenigii L.) chutney powder. Foodserv Res Int. 2004;14(3):175-187.

2. Prabhakara Rao PG, Narsing Rao G, Satyanarayana A, et al. Studies on chutney powders based on tamarind (Tamarindus Indica L.) leaves Foodserv Res Int. 2004;15(1):13-24.

3. Jyothirmayi T, Rao GN, Rao DG. Studies on instant raw tamarind chutney powder. Journal of Foodservice. 2006;17(3):119-123.

4. Narsing Rao G, Prabhakara Rao PG, Jyothirmayi T, et al. Chemical composition, standardisation and storage studies on raw mango chutney powder. Journal of Food Science Technology. 2008;45(5):436-438.

5. Satyanarayana A, Giridhar N, Balaswamy K, et al. Studies on development of instant chutneys from pudina (mint, Mentha spicata) and gongura (Hibiscus sp.). Journal of Food Science and Technology. 2001;38(5):512-514

6. Mishra P, Verma M, Mishra V, et al. Studies on development of ready to eat Amla (Emblica officinalis) chutney and its preservation by using class one preservatives. American Journal of Food Technology. 2011;6(3):244-252.

7. Murray JM, Delahunty CM, Baxter IA. Descriptive sensory analysis: past, present, future. Food Research International. 2001;34(6):461-471.

8. Narsing Rao G, Prabhakara Rao PG, et al. Preparation of instant tomato pickle mix and evaluation of its storage stability. International Food Research Journal. 2011;18:589-593.

9. Prabhakara RPG, Narsing RG, Nagender A, et al. Standardization, chemical characterization and storage studies of an instant pulihora mix based on raw mango. Indian Journal of Traditional Knowledge. 2012;11(1):90-95.

10. Tamilselvi M, Sivakumar V, Ali HAJ, et al. Preparation of pickle from Herdmania pallida, simple ascidian. World Journal of dairy and Food Sciences. 2010;5(1):88-92. 
11. Frankel N. Lipid Oxidation. Dundee: The Oily Press; 1998.

12. Gomez-Alonso S, Mancebo-Campos V, Salvador MD, et al. Oxidation kinetics in olive oil triacylglycerols under accelerated shelf-life testing $\left(25-75^{\circ} \mathrm{C}\right)$. European Journal of Lipid Scienceand Technology. 2004;106(6):36-375.

13. Bunkar DS, Jha A, Mahajan A, et al. Kinetics of changes in shelf life parameters during storage of pearl millet based Kheer mix and development of a shelf life prediction model. Journal of Food Science and Technology. 2014;51(12):3740-3748.

14. Oliveira F, Sousa-Gallagher MJ, Mahajan PV, et al. Development of shelf-life kinetic model for modified atmosphere packaging of fresh sliced mushrooms. Journal of Food Engineering. 2012;111(2):466-473.

15. Tosun I. Color changes and 5-hydroxymethyl furfural formation in zile pekmezi during storage. Grasas y Aceites. 2004;55(3):259-263.

16. Polydera AC, Stoforos NG, Taoukis PS. Comparative shelf life study and vitamin $\mathrm{C}$ loss kinetics in pasteurised and high pressure processed reconstituted orange juice. Journal of Food Engineering. 2003;60(1):21-29.

17. Labuza TP. A theoretical comparison of losses in foods under fluctuating temperature sequences. Journal of Food Science. 1979;44(4):1162-1168.
18. Polydera AC, Stoforos NG, Taoukis PS. Quality degradation kinetics of pasteurised and high pressure processed fresh Navel orange juice: Nutritional parameters and shelf life. Innovative Food Science \& Emerging Technologies. 2005;6(1):1-9.

19. Reyes BA, Pendergast JS, Yamazaki S. Mammalian peripheral circadian oscillators are temperature compensated. J Biol Rhythms. 2008;23(1):95-98.

20. Gyesley SW. Total systems approach to predict shelf life of packaged food products. ASTM STP. 1991:1113-EB.

21. Sadasivam S, Manickam A. Biochemical Methods. 2nd ed. New Delhi: New Age International Publishers; 1997.

22. Prabhakara Rao P, Narsing Rao G, Mala KS, et al. Preparation and storage stability of flaxseed chutney powder, a functional food adjunct. $J$ Food Sci Technol. 2013;50(1):129-134.

23. Martins RC, Lopes IC, Silva CLM. Accelerated life testing of frozen green beans (Phaseolus vulgaris, L.) quality loss kinetics: colour and starch. Journal of Food Engineering. 2004:339-346. 